\title{
Az elveszett paradicsom. A vidéki táj és vidéki élet ábrázolása a somogyi képzőművészetben a 20. század első felében I.
}

\author{
GÉGER MELINDA \\ Rippl-Rónai Megyei Hatókörű Városi Múzeum, H-7400 Kaposvár, Fő u. 10., \\ e-mail: geger.melinda@gmail.com
}

GÉGER, M.: The Lost Paradise. Representation of the Rural Landscape and Life in Somogy's Art in the First Half of the 20th Century, I.

Abstract: The depiction of Hungarian village and rural life appeared as a motif of outstanding significance in 20th-century painting. The representation of the hungarian village and rural life appeared as an outstanding motif in the 20th century painting. The variations in the appearance of the topic are closely related to the transformations of Hungarian society in the 20th century (vagy 20th century helyett:era). The focus is on each in artistic oeuvres to depict the rural sites of civic life and to the myth of a peasant living in harmony with nature and folklorization, elsewhere a new, pantheistic one falls to create a picture of nature. In the artistic oeuvres the focus was on the representation of the civil life's rural locations, on the myth of peasants who live in harmony with nature, more on their folklrisation and elsewhere on a new, pantheistic naturepicture creation. In the first half of the 20th century, this idyll dominates in pictorial expressions describing the concept of rurality. In the first part of the study, different variations of the depictions of the rural idyll appearing in the art of Somogy are reviewed, especially focusing on the art of József RipplRónai. In the first half of the study, the different variations of rural idyll's depictions in Somogy's art are reviewed, especially focused on József Rippl-Rónai’s works.

Keywords: countryside representation, idyll, home-idyll, Lajos Kunffy, Kaposvár, József Rippl-Rónai, small town, interieur

\section{Bevezetés}

A vidék az emberi társadalommal párhuzamosan létező jelenség: a mai civilizációs vívmányok közvetlenül vagy közvetve a vidék világából eredeztethetők. A téma iránti felfokozott érdeklődés a vidékfejlesztés kapcsán újra aktuálissá vált az Európai Unióhoz történő csatlakozás évtizedeiben. A fogalmat számos tudományág vizsgálja, és a sokféle megközelítés következtében máig nincs egyértelmű meghatározása. ${ }^{1}$ Vidék lehet a provincia, országrész, táj, térség, régió, hely, övezet, körzet vagy éppen periféria, külváros, peremváros, határ. Amennyiben a szót az elmaradottság, a valamilyen centrumtól való távolság értelmében használjuk, a pejoratív tartalom dominál. A vidékiség magában hordozza a fővárossal, a centrummal szemben megfogalmazott ellentétet is. ${ }^{2} \mathrm{~A}$ fogalom olyannyira része a magyar mindennapoknak, hogy a közfelfogás a főváros körüli szűkebb agglomerációt

1 Horváth Gergely Krisztián, 2015: Örökségünk és adósságaink: a rurális társadalomtörténet lehetőségei Magyarországon. Ethnographia 3:418.

2 Nagy Géza, 2007: Vidék, vidékiség, vidékfejlesztés fogalomköre. - Vidékfejlesztés. 17 kivéve gyakran az egész országot vidéknek minősíti. ${ }^{3}$

A mindenkori, de tartalmában folyamatosan változó arculat meghatározó tényezője a művészet által sugallt kép. A vidék fogalmához kapcsolva máig tartóan kapcsolódnak a béke, nyugalom és harmónia sztereotípiái. A bennük megrajzolt idill évezredek óta a városlakó polgárság kulturális terméke, konkrét földrajzi helytől elvonatkoztatott, szimbolikus táj, amely ellentéte a konfliktusokkal teli, zaklatott városnak. ${ }^{4}$ A hagyományos, antik eredetű pásztoridillben az iparosított mezőgazdaságot és gépesítést megelőző korok kézművesebb és természetközelibb világa jelent meg. Az ipari forradalom utáni, 20. századi művészetnek továbbra is meghatározó motívumát adják a vidékkel kapcsolatos pozitív képzetek. Jelen tanulmány több részben mutatja be a vidékidill motívumának változatait kifejezetten a Kaposvárhoz és somogyi régióhoz kötődő képzőművészek alkotásaiban

\section{Vidéki társadalom a 20. század elején}

A vidéki élettel kapcsolatos múvészeti toposzok lassú változása az iparosodás és urbanizáció megindulástól figyelhető meg. Kelet-Európában a társadalom nem a nyugati modell szerint modernizálódott: Magyarország megmaradt agrárországnak, amely a nagyvárosi civilizáció eredményeit csak részben asszimilálta. Bár a népesség jobbára vidéken élt és agrárkereső volt, a 19. század második felétől - és különösen a századforduló előtti évtizedektől kezdve - a mezőgazdasági népesség aránya rohamosan csökkent. ${ }^{5}$

A polgárosodás folyamatában mindenütt a középosztály a hangadó és mérvadó tényező. Magyarországon a társadalom leginkább meghatározó befolyással bíró rétegét a közép- és kisnemesség alkotta. E birtokos osztály a reformkorban még a polgárosodás élén állt. ${ }^{6}$ A század második felében a formálódó kapitalista verseny következményeként anyagi helyzete megromlott. A kiegyezést követő fél évszázad alatt körülményeik látványosan romlottak és e folyamatot jellemzi, hogy a nemesi családok száma 14-15 ezerről 6-7 ezerre

3 Csatári Bálint, 2004: A magyarországi vidékiségről, annak kritériumairól és krízisjelenségeiröl. - Területi Statisztika 7. 44: 6. szám, 532-543.

4 Hauser Arnold, 1980: Művészet és irodalom társadalomtörténete, 2. 18.

5 Dr. Kiss Albert, 1961: Az agrárnépességi viszonyok területi alakulása Magyarországon 1880-1960. - Demográfia 1: 4.

6 Bibó István, 1989: Eltorzult magyar alkat, zsákutcás magyar történelem. - Válogatott tanulmányok II. köt. 581-582. 
csökkent. ${ }^{7}$ A szabad verseny nyomán fokozatosan elszegényedő birtokos középosztályban megrendült a nemzeti liberalizmusba és polgárosodásba vetett hit. Leszármazottaik közül kerültek ki a deklasszált, birtokukat elvesztő dzsentrik. A dzsentri a kereskedést és általában a pénzszerzést nemes emberhez nem illő, megvetendő foglalkozásnak tartotta, ezért alapvetően idegenkedett a nemes számára méltatlannak tartott ipari-kereskedelmi tevékenységtöl. ${ }^{8} \mathrm{E}$ nézet elterjedtségére utal, hogy már az 1830-as, 1840-es években már a tudományos gondolkozásban is kifejezésre jutott az a nézet, hogy az üzleti szellem hiánya a magyar nemzet karakteréből fakad. A nemesi társadalom az 1880 -as évektől a politikai privilégiumait érintő polgári fejlődést és a vele együtt járó értékváltást a hagyományos erkölcs és ízlés tagadásaként, illetve a nemzeti önazonosság felbomlásaként élte meg. ${ }^{9}$

A birtokos nemesség számára elsősorban a politikai pálya, a vármegyei, katonatiszti, jogi vagy papi hivatás nyitott. A pályafutás legígéretesebb terepét a vármegye kínálta, amelynek hivatalait szinte kizárólagosan birtokolta. E feudális gyökerekkel bíró társadalmi osztály művészethez való viszonya mérvadó volt a magyar vidék kisvárosaiban. Értékválasztása, elzárkózása a modern létformától és annak szellemi áramlataitól meghatározta a századforduló vidéki világának kulturális orientációját. ${ }^{10} \mathrm{~A}$ dzsentri a nemesi szellem továbbéltetőjeként, saját értékrendje szerint formálta át a kisvárosokban is a hozzá asszimilálódni akaró polgári elemet. Ez a társadalmi réteg tartotta életben a századforduló idejére megingó, romantikus gyökerü népi-nemzeti mủvészetet. ${ }^{11}$ Így a magyar vidék hivatalnokvilágában és értelmiségi rétegeiben a polgári szemléletmód és a realizmus és naturalizmus nagyvárosi eszméjével párhuzamosan továbbra is nagy erővel hatott a nemzeti művészet fogalmával összekapcsolt, idealizáló népnemzeti eszme és a romantikából eredeztethető falumítosz. ${ }^{12}$

Az idealizált vidékkép a 19. századtól vált tipikus motívumává a magyar kultúrának. Még az első világháború traumája után is, amikor a feudális ízlésvilág anakronizmusa már nyilvánvaló, tovább élt a gondolat, melyben a parasztságot tekintették a nemzeti kultúra alapjának és legfőbb hordozójának. A „csak tiszta forrásból" bartóki és kodályi jelszava olyan intellektuális irányt fejezett ki, amely generációkat inspirált. „A rurális és nemzeti azonosítása együtt járhatott a rurális életkörülmények kritikájával, de végső soron a

7 Hanák Péter, 1988: Magyarország társadalma a századforduló idején. - Magyarország története 1890-1918. 458. o.

8 Gaál Zsuzsanna, 2009: A dzsentri születése. A Tolna megyei reformkori középbirtokos nemesség átalakulása a neoabszolutizmus és a dualizmus korában. 20.

9 Szabó Miklós, 1988: Politikai gondolkodás és kultúra Magyarországon a dualizmus utolsó negyedszázadában. - Magyarország története 1890-1918. 920.

10 Németh Lajos,1981: A századforduló magyar kultúrája. - Magyar Művészet 1890-1919. 33.

11 Szabó Miklós, 1988: Politikai gondolkodás és kultúra Magyarországon a dualizmus utolsó negyedszázadában. - Magyarország története 1890-1918. Budapest, 971.

12 Németh Lajos, 1981: A „nemzeti müvészet” jelentésváltozásai.Magyar Müvészet 1890-1919. 101. rurális pozitív imázsát teremtette meg, amelynek alakváltozatai a posztszocialista korszakig is eljutottak" állapítja meg Kovách Imre alapvető vidék-monográfiájában. ${ }^{13} \mathrm{~A}$ magyar identitás megalkotásában jelentős szerepet játszó népi írók a magyarság fennmaradását kivétel nélkül a vidéki életmóddal szorosan összefüggő népi kultúrához rendelték hozzá. ${ }^{14} \mathrm{E} 19$. századból örökölt szellemiségből inspirálódik a vidék szembeállítása a várossal és az a népi-urbánus vita, amely az első világháború utáni korszak idealizáló agrár-szellemiségét erkölcsi tartalommal töltötte fel.

A vidékidill 20. századi történetének egyik kiindulópontjaként tekinthetünk a Magyarország 1000 éves fennállását ünneplő, 1896-ra kitüzött ezredéves ünnepségsorozatra. A Millenniumi Kiállítás pavilonjaiban hangsúlyosan jelent meg a századforduló vidéki Magyarországát bemutató falumodell. A Néprajzi Falu a vidék életmódját, a falvak lakóinak hétköznapjait és ünnepeit házakban felállított viseletes bábukkal, zsánerkép-szerű jelenetekkel reprezentálta. A megjelenített népi életképek néprajzilag hitelesek kívántak lenni, ugyanakkor követték a közkedvelt népszínművek stílusát és a korszak populáris grafikáján terjesztett népéletképek sztereotip beállításait. ${ }^{15} \mathrm{~A}$ Kiállítási Faluban tevékenykedő pásztor, a viseletben vonuló nép, a mulató, táncoló parasztok is a városi élettől elütő, különleges látványosság szerepét is betöltötték, ugyanakkor a századfordulón látványosan modernizálódó fővárosi élet ellenpólusaként is jelentek meg. Mindez a polgáriasodó Budapest és „a vidék” közötti regionális különbségek markáns megjelenésének is jele.

A vidék ellenpontja, Budapest a századfordulóra világvárossá nőtte ki magát: Párizs és Berlin mellett Európa nyolcadik legnagyobb városa és egyik kulturális központja. Az első világháborút és a trianoni békeszerződést követő időszakban eltűntek a gazdasági és kulturális szempontból legmeghatározó vidéki nagyvárosok, Kolozsvár, Pozsony, Kassa, Nagyvárad, Arad vagy Újvidék. Így Budapest egyedüli nagyvárosként maradt az országban, és jelentősége a korábbiakhoz képest jelentősen megnőtt. Az újabb, két háború közti negyedszázad periódusát végérvényesen a főváros térfoglalása jellemzi. ${ }^{16}$

Magyarországon a nemzeti romantika keltette fel az érdeklődést a népművészet és a vidéki élet iránt. A 19. század a nemzeti szellemet az eszményített vidéki életmóddal és értékrenddel azonosította, melyben a falu és a paraszt a nemzeti kultúra letéteményese és hordozója. Az imázsteremtők ugyanakkor kihagyták azokat az elemeket, amelyek nem egyeztek képükkel. Csak a 20. század elején jelent meg a szegénység, a kirekesztettség formáinak ábrázolására az ellen-idill.

13 Kovách Imre, 2012: A vidék az ezredfordulón. A jelenkori magyar vidéki társadalom szerkezeti és hatalmi változásai. 32

14 Bimbó Mihály, 2013: A népi írók mozgalmáról. - Eszmélet, 99: http://www.eszmelet.hu/bimbo_mihaly-a-nepi-irok-mozgalmarol/

15 Dóka Krisztina, 2019: „Népünnep” és nemzeti ünneplés (1896) Népszokás- és néptáncbemutatók az Ezredéves Országos Kiállításon. - Tánctudományi Közlemények 9: 48.

16 Gyáni Gábor, 2005: Budapest túl jón és rosszon. - Beszélő 10: 3 http://beszelo.c3.hu/cikkek/budapest-tul-jon-es-rosszon 
Ez utóbbi, kritikai képeken már a vidéken élők életkörülményein, a szegénységen, kiszolgáltatottságon van a hangsúly. A valóságfeltárásra irányuló igény az első világháború után színre lépő népi mozgalommal erősödött meg. A két világháború közti időszakban, amikor felgyorsult a parasztság hagyományos életformájának bomlása, Szabó Zoltán keserüen jellemzi a hanyatlás folyamatát: „... a civilizáció javainak alja egyre szivárog le a faluba. Értékben semmi módon nem ér fel azzal a parasztkultúrával, melynek utolsó maradványait pusztítja, és most már az emlékeit is pusztulással fenyegeti. "17 A 20. században meghatározó a nemzeti és a vidék összekapcsolásának idealizáló illetve a kritikai vidékkép realizmusának ellentmondása. ${ }^{18}$ Utóbbi művészetben történő lecsapódása különösen a 20. század második felében regisztrálható.

\section{A vidéki idill motívumai a század első felében}

A századforduló első két évtizedében Magyarország a soknyelvű monarchia része, erős önállósodó törekvésekkel, önálló, orientációiban szabad választásokat követő kultúrával. A monarchia világlátott polgárságának vidékidillje az egyetemes kultúrába való integrálódás igénye mellett jelentkezett somogyi képzőművészek, elsősorban Rippl-Rónai József, Vaszary János és Kunffy Lajos munkásságában. (Az alföldi művészet mélyrealizmusa és társadalomkritikája Somogyban egyáltalán nem jellemző.) Ezek a művészek születésük, itt tartózkodásuk vagy családi hagyományaik alapján szorosan kötődtek a régióhoz. Az adott vidéki táj azért érdekelte őket, mert érzelmileg ez biztosította számukra a meghitt, otthonias környezetet. A vidékröl és faluról megkonstruált képük - amely szemben áll az iparosodással és a modern nagyváros homogenizáló törekvéseivel - az aranykori, eltűnőben lévő világ feletti sajnálkozás érzését is magában hordozza és. (Az utóbbi jelenséget csak Vaszary János dolgozta fel az 1930-as évek képeiben.) Érdekes kísérlet Bernáth Aurélé, amely a helyi, lokális szintet meghaladó, de alapvetően a vidékhez kötődő természetelvű festészet kidolgozására példa.

A tanulmány első és második részében sorra veszszük a vidékidill legfontosabb jellemzőit, amelyek helyekben és motívumokban meghatározó összetevői a következők:

Vidék és város életmódbeli szembeállításában gyakori vélekedés, hogy a vidéki kultúra sokkal statikusabb, mint a városi. Mozdulatlansága, állandósághoz való ragaszkodása évezredes hagyomány. Szociológiai kutatásokban megjelenő nézetek szerint a „vidéki élet nyugalmasabb, kevesebb a stressz, a vidéki ház a béke szigeteként jelenik meg. .. A városban zaj és rohanás van, ami stresszessé teszi az embert szemben a vidék csendjével és békéjével."19 A 20. század első felében a vidék mint elkülönült társadalom jelenik meg a képzőművészeti alkotásokon. Zártsága, lehatároltsá-

17 Szabó Zoltán, 1937: A tardi helyzet. 152

18 Kovách Imre, 2012: A vidék az ezredfordulón. A jelenkori magyar vidéki társadalom szerkezeti és hatalmi változásai. 32.

19 Csurgó Bernadett 2013: Vidéken lakni és vidéken élni. 226. ga a belső béke, a nyugalom és változatlanság garanciája. Rippl-Rónai és Kunffy otthon-idilljei ennek a koncepciónak képi megfelelői. Békesség, gondtalanság, nyugalom alkotják e bukolikus létállapot fő vonásait. A helyek lokalizáltak, nem ültethetők át máshová, az ide kötődő emberek karaktere a hely sajátosságához illeszkedik. Az elvonulásban a művész a személyes boldogság utópiáit véli feltalálni. Rippl-Rónai számára a Róma villa meghatározott sajátosságokkal leírható, zárt tér. Az otthoni milliő állandósult motívumai, a bóbiskoló családtagok, ismerős berendezési tárgyak sora adja a biztonság érzését. Kunffynál a somogytúri kúria kínálja ugyanezt a „menedéket”. Nála az ismerős somogytúri emberek, a birtokon történő gazdálkodás, az évszakok és a mezőgazdasági munka ritmusa hordozza magában az otthoniasságot (1. ábra).

A vidéki-kisvárosi idill meghatározó alkotórésze, a közösséghez tartozás érzése az ember természetes igényét kifejezi ki az individuális város elidegenedettségének ellensúlyozására. ${ }^{20}$ Vidéken mindenki ismeri egymást, a szomszédsági kapcsolatok élőbbek, a helyi közösségi élet és a szoros kapcsolati háló a vidéki közösség ethoszának egyik uralkodó eleme. ${ }^{21} \mathrm{E}$ közösségi háló mellett a vidék jellegzetességének tartják az erős, élő rokonsági kötelékeket, melynek legfőbb leképezője a család. Rippl-Rónai kisvárosi idilljei ezt a családias otthonosságot és az egymáshoz tartozás kedélyességét közvetítik.

A vidéki táj egyértelmüen az agrártermelés helyeként azonosítható. Rippl-Rónai és különösen Kunffy Lajos számos múve örökíti meg a birtokhoz vagy uradalomhoz kapcsolódó mezőgazdasági munkát és az ott tevékenykedő embereket. A parasztember Vaszary művein súlyos és erőteljes, szinte heroikussá növesztett alak, míg Kunffy Lajosnál a karakter egyediségében fogható meg. Egy hazatérő aratókat ábrázoló festménye még Ferenc József elismerését is elnyerte. ${ }^{22}$ A két művész parasztembereire kevéssé jellemző az a fajta kiszolgáltatottság, ami az alföldi művészeknél megfigyelhető (2. ábra).

Az etnikai kisebbségek közül a cigányság szintén Kunffy Lajosban találta meg az egyik korai és egyben autentikus tolmácsolóját. A primitív társadalmakra jellemző gondtalanság, a természettel való tökéletes összhang és a vagyon hiányával együtt járó életmód a vidékidill elfogadott része, egyúttal múveinek fontos alkotóeleme (3. ábra).

A vidéki társadalmakban fontos szerepe van a tradícióknak. A szokások, az élet általános rendjét tükröző kultuszok megélése a vidéki élet ritmusának természetes része. „A vidéki emberek sokkal hagyománytisztelöbbek, vannak még helyi hagyományok, amit érdemes ápolni. Ezek a hagyományok döntően a parasztsághoz köthetők, és erős közösségteremtő szerepük van ma is. A hagyomány fontos eleme továbbá a parasztház, ami néhány esetben a vidék megőr-

20 Csurgó Bernadett 2013: Vidéken lakni és vidéken élni. 238

21 Csurgó Bernadett 2013: Vidéken lakni és vidéken élni. 227

22 Kunffy Lajos, 2006: Visszaemlékezéseim. 72. 


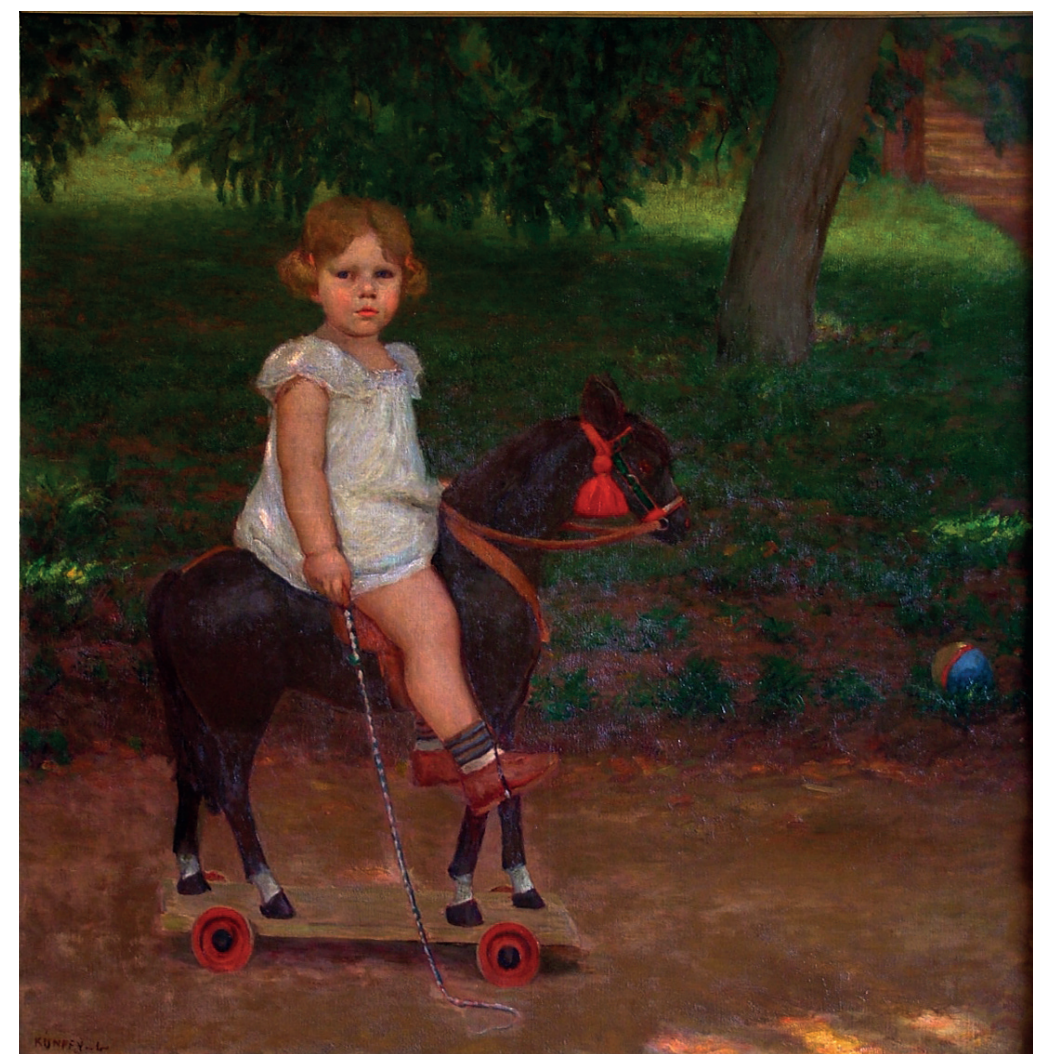

1. ábra. Kunffy Lajos: Fiam hintalovon, 1905. vászon, olaj, 131x130cm, Rippl-Rónai Múzeum, Ltsz: 64.230.

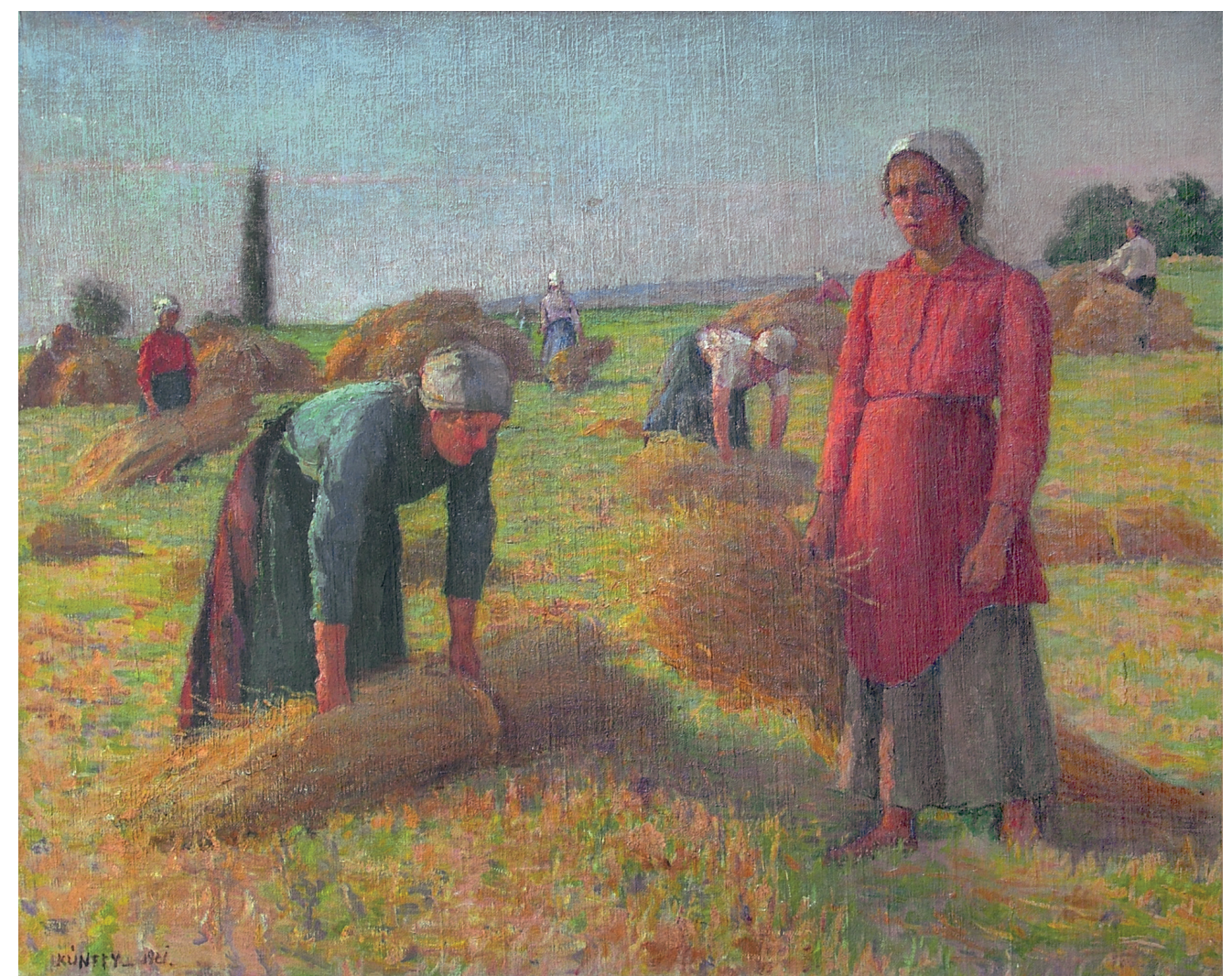

2. ábra. Kunffy Lajos: Kévehordók (Aratók), 1921. vászon, olaj, $80 x 100$ cm, Rippl-Rónai Múzeum, Itsz: 64.92. 


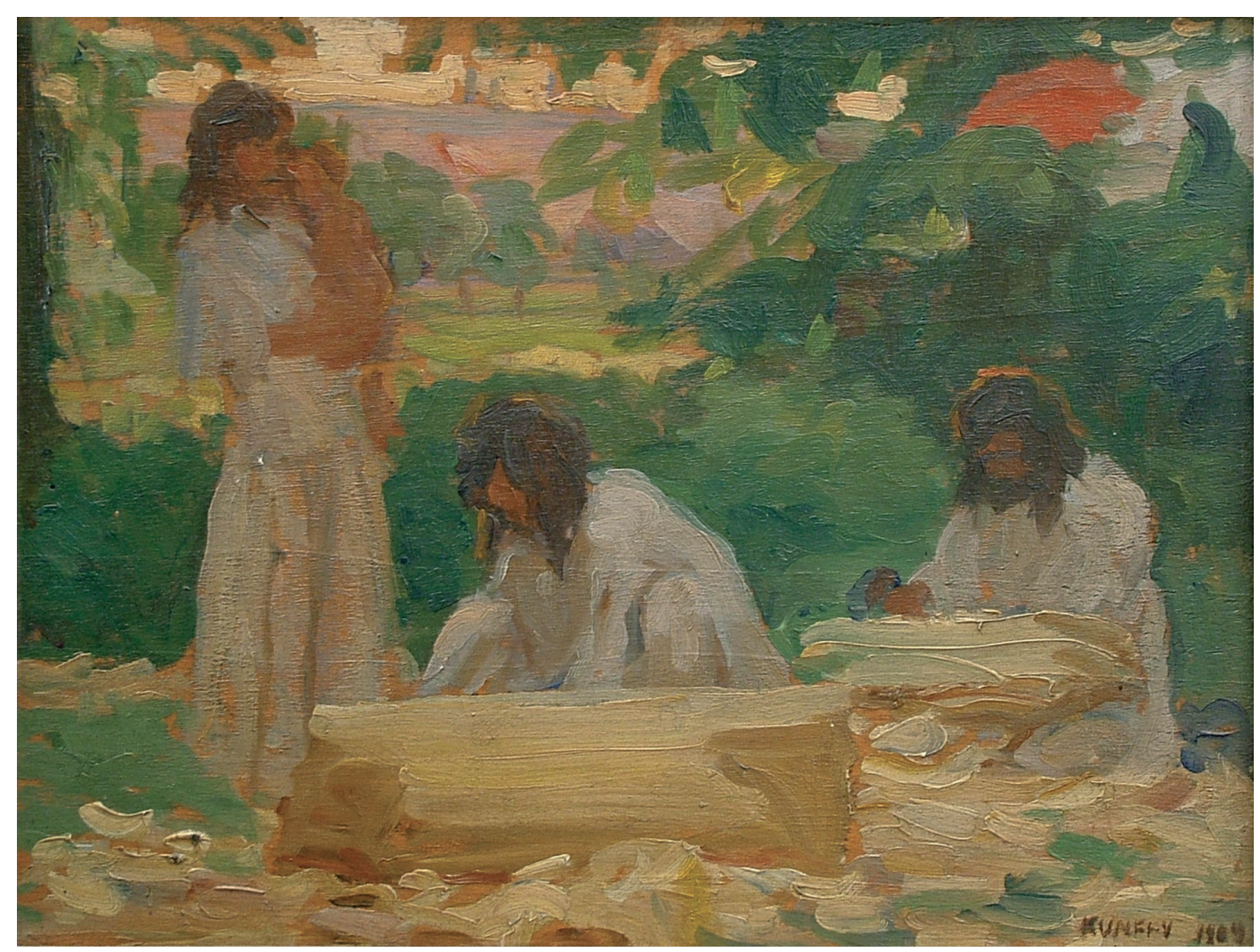

3 ábra. Kunffy Lajos: Teknővájó cigányok (Cigány család), 1911. karton, olaj, 78x70cm, Rippl-Rónai Múzeum, Itsz.: 64.22.

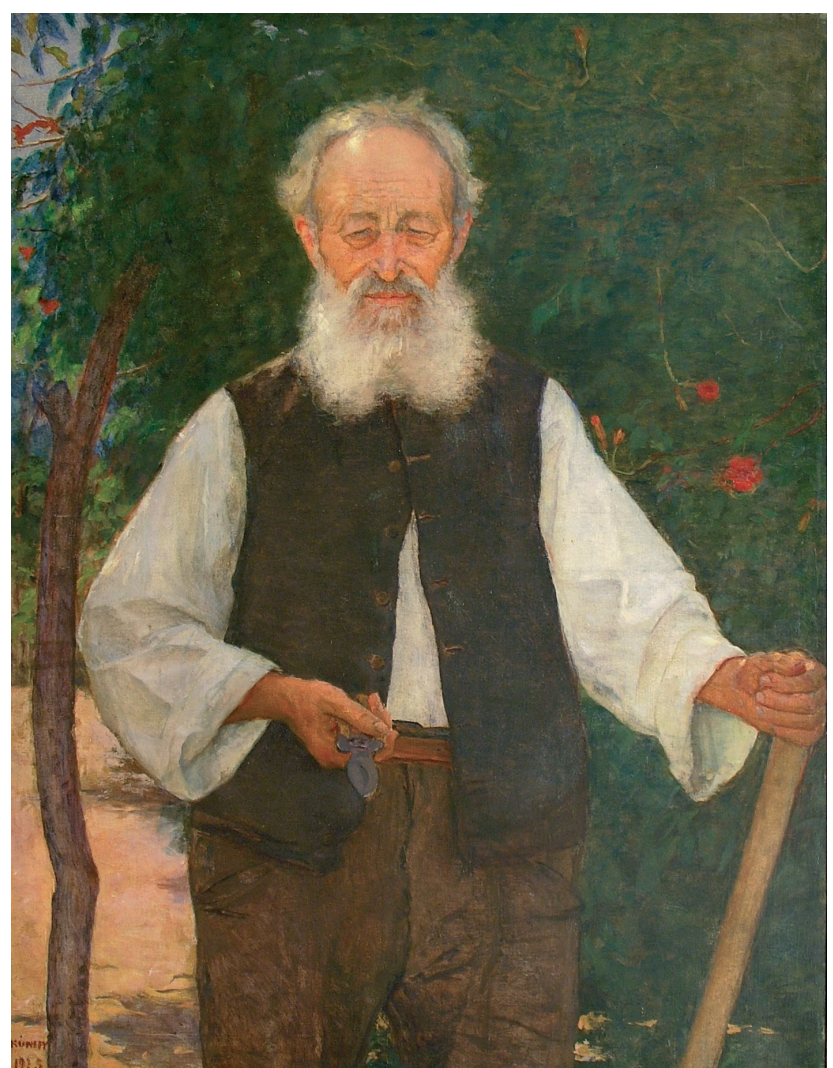

4. ábra. Kunffy Lajos: A látrányi kertészkedő tiszteletes, 1925. vászon, olaj, $116 x 90$ cm, Rippl-Rónai Múzeum, Ltsz: 55.499 . 


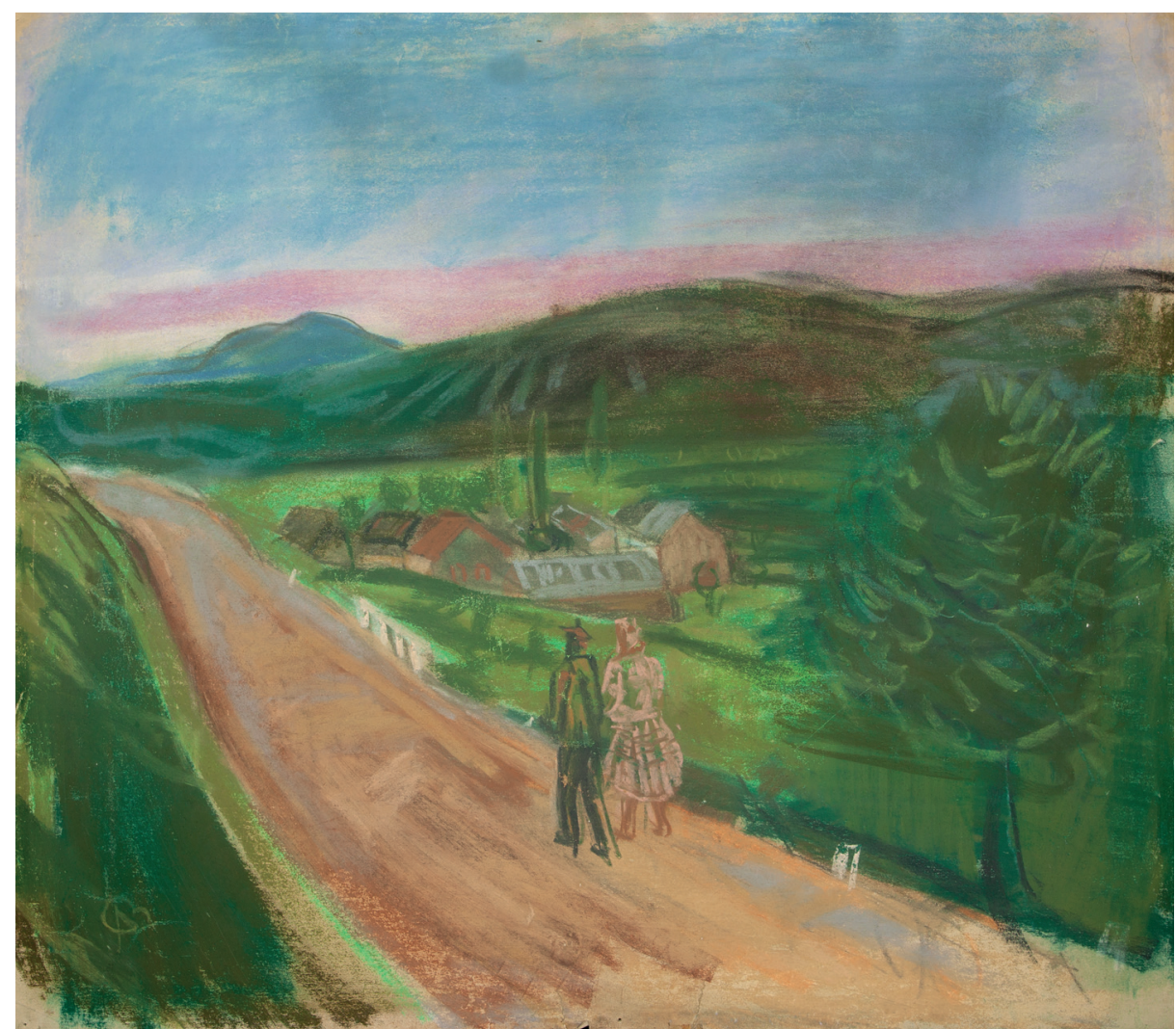

5. ábra. Bernáth Aurél: Országúton (Kaposvári táj) papír, pasztell, 50x57 cm, Rippl-Rónai Múzeum, Itsz.: 87.2.1.

zendő tradíciójának fő elemeként jelent meg"23 A szokásrendek Kunffy Lajos társadalmi együttmüködést ábrázoló népi világának is részei: a lakodalom vagy az aratóünnep különösségéi egyben egzotikus sajátosságát is adják e világnak.

A vidék társadalmára a század első felében újra konzerválódó feudális viszonyrendszer következtében különösen jellemző merev társadalmi rétegződés. A falu nem soha nem volt egységes világ, és az aláfölérendeltség itt hangsúlyosabban és demonstráltabban jelenik meg, mint a városokban. Noha a társadalmi osztályok száma kevesebb, mint a differenciáltabb városban, a kasztok közti hierarchikus különbségek és a szabályok sokkal merevek. Kunffy Lajos festményei ebből az alá-fölérendeltségi viszonyból eredő státuszoknak, a falusi birtokosi és a földműves réteg különböző karakterportréinak érdekes dokumentációi (4. ábra).

Utoljára hagytuk a vidékmítosz legerőteljesebb motívumát, a természeti reprezentációt. A vidéki táj természet közelsége miatt a zölddel, az érintetlen táj szépségével is összekapcsolódik. Ez a pihenés, a meditáció helye, amibe a természet tisztelete is beletartozik. Szociológiai kutatásokban ma is „a kiköltözés okaként is központi helyet foglal el a vidék, mint természetes, zöld lakókörnyezet vonzása, együtt a város taszító hatásával." ${ }^{24} \mathrm{~A}$ képzőművészeti alkotásokon megjelenő tá

23 Csurgó Bernadett 2013: Vidéken lakni és vidéken élni. 228. 24 Csurgó Bernadett, 2013: Vidéken lakni és vidéken élni. 145 hangsúlyos kerete a vidéki életnek. Kiemelt szerephez Bernáth Aurél műveiben jut, ahol a természetközelség egyetemes létélményben oldódik fel (5. ábra).

A fenti motívumok jól körülhatárolják a vidéki élet legfontosabb szimbolikus tereit és szereplőit: a kisvárost, a falu és a parasztember világát illetve a természet lokalizált helyszíneit. A következő fejezetekben bemutatjuk azokat a müveket, amelyek a somogyi képzőművészetben imázsteremtő hatással bírnak. Jelen tanulmányban a vidék szó alatt nem csak falusi övezetet értjük, hanem az egykori vármegyét és annak székhelyét. Kaposvár a falvakhoz képest egyértelmủen város, ugyanakkor nem olyan értékủ centrum, mint a jóval nagyobb vonzáskörzetet magába foglaló régiós nagyvárosok. A századfordulón lakóinak jelentős hányada első generációs városlakó, vidéki kötődéssel, nemcsak a rokoni szálakat, hanem a mentalitást is ide értve.

\section{A kisvárosi élet és a művészet - Kaposvár a szá- zadfordulón}

Somogy a századfordulón az ország egyik legnagyobb hitbizományi megyéje szinte kizárólag agrár jellegű termeléssel. A kisgazdaságok és a helyi középbirtokok háttérbe szorultak a nagybirtokok mellett. Mivel Kaposvár környéke ásványkincsekben szegény, nagyobb ipartelepítést a kormányzat meg sem kísérelt. A város összekötővonalak hiányában a nagyvilágtól elzártan feküdt Egyetlen igazi utcája, a Fő utca, mintegy 
$3 \mathrm{~km}$ hosszan húzódott végig a településen - elágazással alig tagolva. A környék mezőgazdasági művelés alatt álló terület volt körös-körül. A városiasodás a 19 század utolsó évtizedeiben kezdődött. Robbanásszerű gyarapodás állt be a lakosság létszámában. A mai városközpont arculata ekkor alakul ki, a derékszögű utcák új rendszerében a gazdagodó polgárság reprezentatív igényeinek megfelelően nagyvárosias eklektikus épületeket emeltek, amely megváltoztatta a város eredeti képét. ${ }^{25} \mathrm{~A}$ változáshoz első lendületet a gyorsvasút adta, ami a pécsi vonalba kapcsolva a Budapest- Fiume vonalon közlekedett. A posta megjelenése is segített kiemelni Kaposvárt falusias jellegéből. ${ }^{26}$ Lendületet adott 1890-ben a Magyar Általány Bank Kaposvárra települése, amely az ország legnagyobb pénzintézetének számított. A társaság tisztviselőinek létszáma az 1890-es megtelepedéskor még 12 föt tett ki, közöttük komoly elméleti felkészültséggel bíró szakemberek. A részvénytársaság telepítette az alapvetően agrár-jellegü Somogyba a cukorrépa feldolgozó gyárat. A szaporodó községi adó, illetve a létesülő új munkaalkalmak révén és a tőke városba áramlásával a polgárosodás folyamata fokozatosan megindult és a városi értelmiség létszáma is megnövekedett. ${ }^{27}$ Ugyanakkor Somogy továbbra is feudális jellegü agrármegye maradt, és öszszességében azt a szellemi középszerüséget képviseli, ami a vidéki Magyarországot mindenütt jellemezte. Kis szigetet képez néhány múvész, író, tanár, kereskedő és a városban élő értelmiségiek, akik polgáriasultabb eszmevilága elütött a nagy átlagtól. Ide tartozik elsősorban Rippl-Rónai József, aki 1901-ben, hosszas párizsi tartózkodás után települt le szülővárosába. E művelt, világlátott rétegnél jóval többen vannak a kevésbé müvelt kispolgárok, akik népszínműveken iskolázott ízlésvilágát a többség elfogadta.

Kaposváron a festészeti másodvonal képezi a művészeti élet gerincét - viszonylag képzett, külföldön is iskolázott kismesterek. Saját vagyon és egzisztencia nélküli művészemberként jobb esetben a város alkalmazottai, akik belesimulva a kisvárosi életbe egy-egy fögimnáziumi rajztanári állást foglalhattak el, rosszabb esetben eltartottjai. ${ }^{28}$

Aszázadforduló előtti évtizedekben három tehetséges fiatal indult útnak a művészi pályára, akiknek munkásságában meghatározó módon nyomot hagyott a vidék. Elsőként Rippl-Rónai József (1861-ben), később Vaszary János, majd Kunffy Lajos. Őket követte a két világháború közti korszakban Bernáth Aurél. Munkásságuk gyökere a szülőhely vidéke, gyermekkorukat is a vidéken töltötték, kötődnek a kisvárosi-vidéki világhoz, ugyanakkor tanulmányaik és életútjuk révén szoros a kapcsolat füzi őket

25 Szijártó István: Kaposvár közművelődésének és művészeti életének áttekintése a századfordulótói a felszabadulásig. Rippl-Rónai Múzeum, adattár. kézirat, 5

26 Fekete Gyula, 1929: Az ötven év elötti Kaposvár. Új-Somogy Nyomda, Kaposvár, 24

27 Szíjártó István: Kaposvár közművelődésének és művészeti életének áttekintése a századfordulótói a felszabadulásig. Rippl-Róna Múzeum adattár. kézirat, 4

28 Géger Melinda, 1992: Galimberti Sándor indulása (A művész tanulóéveinek rekonstrukciója 1883-1903-ig Kaposvártól-Nagybányáig) - Somogyi Múzeumok Közleményei 9: 125. a nagyvilághoz, olyan városokhoz, mint Párizs, Berlin és Budapest. A helyi közeg számukra nem csak Kaposvárt, hanem a környező falvakat is jelentette. Családjukban mindenütt jelen van az elszegényedett kisnemesi vonal. Bár a vidék szülöttei, nem olyan módon ábrázolói ennek a világnak, mint az alföldi festők. A vidékhez füződő viszonyuk a mindennapi kapcsolat eredménye: szeretettel, de kívülröl nézik az igazi vidéket, és annak egy magukra adaptált, stilizált képét teremtik meg múvészetükben. Ugyanakkor a vidéki létforma interpretációi - minden személyesség és belső átéltség ellenére - egy mesterségesen megkonstruált modell, amiben régóta továbbélő toposzok mutathatók ki.

\section{A kisvárosi idill és az otthon kultusza Rippl-Rónai József munkásságában}

„A múlt századi és a századfordulós Magyarországra a falu, illetve a falu és város közötti civilizációs képződmény, a kisváros volt a leginkább jellemző. A nemzet kulturális összképe ebböl a vidékies-kisvárosi környezetből indult". ${ }^{29}$ A kisváros adja azt az esztétikaikulturális közeget, amelynek romlatlanságát dicsérték és ahová sokan visszavágytak. Kaposvár e mikrovilágát örökítette meg Rippl-Rónai József, akit szülővárosához legfontosabb művészi élményei füzik.

Apai rokonsága a környékbeli falvakból érkezett Kaposvárra. A felmenői közt először az édesapja lett tanító végzettségü értelmiségi. Többi nagybátyja kézműves, asztalos vagy bognár, de a szoros összetartozás érzése mindig összekötötte a család férfitagjait. A művész franciaországi tartózkodása alatt, Banyls-ben dőlt el, hogy a vidéki világ vonzza és tájmotívumokat akart gyüjteni. (Párizsban sem un. városi, inkább műtermi festőként dolgozott.) Festői témakörének ihlető világa alapvetően a vidék. Otthonához, testvéreihez és szüleihez közel, Somogyban kereste azt a világot, ami gyermekkorának alapélménye volt. Rippl-Rónainak két híres sorozata kapcsolódik a városhoz: egyik az első otthona, a Fö utcai ház, ahol enteriőrkorszak, másik a Róma villa, ahol a kukoricás stílus idilljei készültek. Kaposvár mindössze 1-2 képén szerepel: a város, mint topográfiai helyszín vagy utcakép nem jelentett számára festői kihívást. Helyette egy szűkebb közeg, az otthon és a család, mint a kisvárosi atmoszféra legkifejezőbb hordozói vonultak be a Kaposvár-képek közé.

Kaposvárra visszatérve Rippl-Rónai egy számára meghitten ismerős régi életben és szokásrendben találta magát. A kisvárosokban a családi házat a középosztályhoz tartozás fontos feltételének tekintették, a társadalmi státusz lényegi kifejezője volt. Kaposvári házába a letelepülő müvész nagy gonddal válogatta össze bútorait, amelyeket később a Róma villába is magával vitt. Ízléséhez közelebb álltak a rusztikus darabok, melyek elütöttek a kor reprezentációra törekvő, historizáló, de még a modernségnek teret engedő városi otthonok szecessziós berendezéseitől is. Az 1906-s kiállítás ké-

29 Király Erzsébet, 1998: A kisváros és az otthon képei. Rippl-Rónai kaposvári interieur-korszakáról. - Rippl-Rónai József gyűjteményes kiállítása. 74 


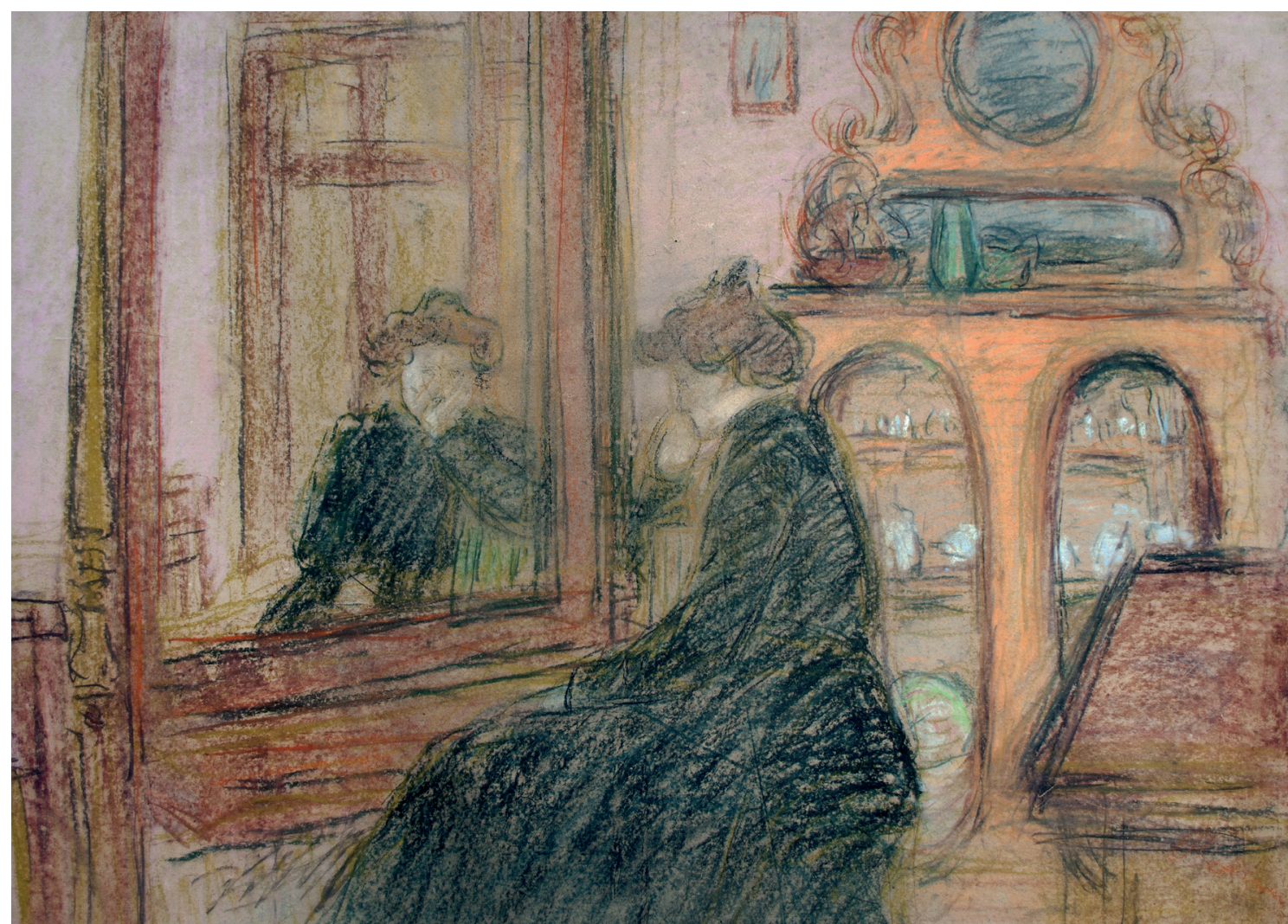

6. ábra. Rippl-Rónai József: Lazarine a tükör előtt, 1901 k. papír, pasztell, 45x65cm, Rippl-Rónai Múzeum, Itsz.: 55.621.

peiben egyes darabok állandósult ismerősökként térnek vissza-vissza: a puritán biedermeier hálószoba, a csíkos késő-biedermeier szalongarnitúra, szekreter, a fekete kredenc vagy a tálalószekrény, melyek statikáját az „áramvonalas” karosszékek, kerek asztalok egészítik ki. „Én kis feleségemmel letelepedtem Kaposban, kis fehér viskónkban, ahol minden, a sok virág, sok más kedves dolog, emlék mosolyog ránk, amikről naphoszszat elbeszélgetünk, és nélkülözhetővé teszi a banális világot, amely körülöttünk hemzseg minden ideális érzés nélkül" - tudósította új otthonáról barátját, Kunffy Lajost. ${ }^{30}$ A szembeállításban megjelenik a kinti és benti világ ellentéte: a bensőséges ideális és az érzés nélküli, hideg külvilág ellentéte. A lakás a polgárosodás során vált a városi középosztályi családok szigorúan védett intim szférájává szemben a munka és a nyilvánosság elidegenedett világával. Az otthon a visszavonulás biztonságos terepe, ahol a családfőt bizalom, nyugalom és a „családi tüzhely melege” várta. ${ }^{31}$ „Itt, ebben a meleg, puha otthonban érzem magam igazán jól. Az intim életből merítem témáimat, mert ezt az életmódot szeretem és respektálom." - vall új, ihlető környezetéröl. ${ }^{32}$

30 Rippl-Rónai 1903. november 23-án, Kaposváron kelt levele Kunffy Lajosnak. MNG Adattár, Itsz: 19761/77/1

31 Fónagy Zoltán, 2015: A polgár otthona a boldog békeidőkben: ideál és valóság. 2015. február 8 . https://mindennapoktortenete. blog.hu/2015/02/08/polgari_otthon

32 Lázár Béla, 1906: Látogatás a müteremben Rippl-Rónai Józsefnél. - Modern Művészet, 1906. 4: 202
E korszakában Rippl-Rónai számára a belakott tér és az ember kapcsolata, egymásra gyakorolt hatása válik festői problémává. Interieurjeinek szerkesztésében az idill toposzának évszázadok óta alkalmazott, zárt jellege érvényesül. Motívumainak összetartozása adja a belső rendet képező zártságot. A tárgyak jelentésüktől függően a kinti világ reflexiói. A mikrovilág lényegi létformája a befelé fordulás. Még a halál is stilizáltan jelenik meg ebben a kisvilágban pl. a fekete kendő motívumával. A belső tér a kinti kicsinyített ellenpontja, statikus és mozdulatlan univerzum, ahol észrevétlen körforgásban csordogál az idő. ${ }^{33} \mathrm{Az}$ interieur-ök kerete az állandóság, melyet a visszavonult élet kulisszái, a bútorok és az állandósült modellek, a hozzátartozók tesznek személyessé (6. ábra).

Az emberalakok a berendezési tárgyakhoz hasonló, passzív szerepet kaptak és cselekvés nélküli jelenlétük révén válnak a belső tér mellékrendelt alkotórészeivé. A hagyományos, 19. századi életkép sajátos átértelmezésének vagyunk tanúi, ahol a portrék átfordulnak az enteriőrbe vagy az életképbe. ${ }^{34}$ Rippl-Rónai kutatta, gyűjtötte és felhasználta a különböző kisvárosi karaktertípusokat - ő maga foglalkozás szerint sorolja őket. ${ }^{35}$

33 Keserü Katalin, 1998: Műfajok és mütípusok Rippl-Rónai művészetében. - Rippl-Rónai József gyüjteményes kiállítása. 130.

34 Keserü Katalin, 1998: Műfajok és mütípusok Rippl-Rónai művészetében. - Rippl-Rónai József gyűjteményes kiállítása. 128.

35 Rippl-Rónai József Emlékezései/Beck Ö. Fülöp emlékezései. 1957, 86 
Modelljeit azonban a Párizsból magával hozott, sommázóan lényegretörő látásmóddal, távolságtartó módon készíti el. Piatsek bácsi megsértődött azon, hogy túl nagy orral, karikírozva ábrázolta a művész. ${ }^{36}$ Ezek a portrék fölényesen áttranszponáltak, szinte karikatúrává lényegítettek, és látásmódjukban a polgári világlátottság kívülálló bölcsessége is megnyilvánul.

A családtagok eseménytelen élete és zárt milliője a vita contemplativa végtelenített poézisét adja. A nyugalomra, elmélkedésre építő, szemlélődő idillbe menekülő létforma számos képen sugallja a kontemplatív életérzést: olvasó, bóbiskoló, háttal ülő vagy merengő nőalakok, töprengő, pipázgató vagy borozgató férfialakok: a táblabíró világ ráérős, bölcselkedő semmittevésének szereplői. A bölcsességgel határos testi és szellemi passzivitás és vágy nélküli elégedettség az ókori idillek eredendő eszményi létformája, amely a 19. századra a középosztályok életideáljává szélesedett.

Rippl-Rónai számára a Kaposvárra való visszaérkezés nem beleolvadást jelent, hanem némi szeretetteljes fölényt és bölcs sommázását annak, hogy „mivé lettünk”. Rippl-Rónai 1906-os sikerének valószínű oka e világ lelkiségének őszinte tolmácsolása, amit a közönség mélyen átérzett. A magyar polgár mentalitásának megalapozott kulturális tradíciója sokkal inkább megfelelt a vidékhez és népességéhez füződő, biedermeier gyökerü, enyhén rezignált érzelmi élménynek, mint a párizsias nagyvilág frivolitásának.

\section{A kúria magasából ...}

Polgári megrendelőréteg hiányában a kastélyokat birtokló arisztokrata családok komoly szerepet játszottak a hazai mecenatúrában. Rippl-Rónai az 1890-es években került kapcsolatba Andrássy Tivadar gróffal, akitől ebédlőjének tervezői megrendelését kapta. A gróf családját gyakran meglátogatta a tőketerebesi kastélyukban is, és leveleiben rendszeresen panaszkodott a megrendelések nehézkessége miatt. Kaposvárra való visszatelepülése után határozottan törekedett arra, hogy Andrásssy ebédlőhöz hasonló megbízásokat kapjon. Diákkori földbirtokos barátja, Somssich Géza közvetítésével jutott meghívásokhoz a kivadári, a körtvélyesi, a somogygeszti, az alsóbogáti vagy a bárdudvarnoki kastélyokba egy-egy vadászatra vagy nyaralásra, ahol a helyi szellemi elit találkozott. ${ }^{37} \mathrm{~A}$ nagyvárostól távoli, idilli élet színhelye évszázadok óta a vidéki kastély, kúria vagy nyaraló volt. A villareggiatura reneszánsz álmának megvalósítására a társadalom legfelső rétegének volt lehetősége. A művész az ilyen vendégeskedésekkor a maga módján próbált megrendeléseket szerezni: szorgalmasan festett. Járt Körtvélyesen, Lesznay Anna családjánál, Halmos Imre somogygeszti kastélyában és Kunffy Lajost is többször meglátogatta Somogytúron. ${ }^{38}$ Bárdudvarnokon Goszthony Mihály földbirtokos meghívására fordult meg, és festői előmenetelre vonatkozó tanácsokat

36 Horváth János, 1995: Rippl-Rónai emlékkönyv. 19.

37 Horváth János, 1995: Rippl-Rónai emlékkönyv. 87.

38 Horváth János, 2011: Rippl-Rónai 150. 87 adott a család leányának. Goszthony Máriát később Budapesten a Haris közi esti iskolában is tanította rajzolni. ${ }^{39}$ Goszthony Mária közlése, hogy Somssich Géza Kopaszhegyi vadászkúriájának belső falait széles csíkokkal saját kezűleg festette ki. ${ }^{40}$ Rippl-Rónai reménykedett, hogy megbízásokat kap a helyi arisztokrata családoktól, de reményeiben gyakran kellett csalatkoznia. A vendégeskedések nyomán keletkezett több mint 10 , kúriákat ábrázoló sorozata. ${ }^{41} \mathrm{E}$ kúriaábrázolások sajátossága, hogy Rippl-Rónai a központi motívumként szolgáló kastélyépületeket hangsúlyos parkészletekkel egészítette ki. A kastély általában a dús pompával virágzó virágágyás mögött, rejtve húzódik meg. Emberalak ritkán jelenik meg, ha igen, akkor alárendelten, amint azt a Körtvélyesi kastély kétféle változatán látjuk. Ezáltal a művész az épület hívogató, vonzó jellegét emeli ki.

A vidéki táj vonzotta a korabeli festőket. Magyarországon Nagybánya, Szolnok, Kecskemét, Hódmezővásárhely, Gödöllő és Nyergesújfalu művésztelepei is a szabadba való kivonulás gondolatára alapozták programjukat. Nem véletlen, hogy a 19. század városlakó impresszionistái „fedezték” fel újra a zöld övezetet és a természetet. Megszokottá vált a szabadidőben a kirándulás „zöldbe”, a menekvés a város elidegenítő, nyomasztó hangulata elöl. Rippl-Rónai éppen Somogytúron vendégeskedett Kunffy Lajosnál, amikor Lajos testvére az eladó Róma villára hívta fel a figyelmét. ${ }^{42} \mathrm{~A}$ Róma hegy gyermekkori kirándulásainak helyszíne volt. A művész 1906-os budapesti kiállításának bevételéből kis vagyon jött össze így a birtok megszerzése megvalósult álommá vált. A villa és a hozzá kapcsolódó kb. 14 holdas kisbirtok gazdálkodásra alkalmas terület volt szőlővel, szántóval, réttel, továbbá gyümölcsöst is magába foglalt (7. ábra). A festő felesben müveltette a gazdaságot, ő maga nem tanult bele a gazdálkodásba, annak ellenére, hogy Kaposváron elsősorban a Róma villa tulajdonosaként, földbirtokosként volt elkönyvelve. ${ }^{43}$ Képeladásait föként zsidó származású ügyvédek illetve az orvosok családi arcképei jelentették (családfő, feleség, gyerek), sok esetben a Róma villához megrendelt munkát fizette ki a festményeivel.

A kaposvári Róma-hegyen álló új otthon környezetében megélt élmények nyomán számos mü született. Képcímeiben beszél a birtokon zajló gazdálkodásról és az ottani életről is: Gyüjtik a szénámat kaposi kertemben; Berakják a gabonát estefelé; Kukoricaszedés; Az én nyíresem vágáskor télen. A gazdálkodás munkáját bemutató képein Rippl soha nem az ember, inkább a táj karakterével foglalkozik: a dolgozó emberalak a képi egységnek alárendelt, szervesen hozzátartozó, de mellékékes tényező.

\footnotetext{
39 Horváth János, 2008: A Rippl-Rónai tanítványok. Rippl-Rónai művészetének hatása az 1910-es években Kaposváron, 339.

40 Goszthony Mária szóbeli közlése Horváth Jánosnak. 1985 k

41 Genthon István feljegyzései, MTA MKCS-C-I-36/2206, 2217, 2359, 2367, 2386, 2403, 2431, 2434, 2437, 2685, 2711, 2975

42 Horváth János közlése a szerzőnek, 2019.

43 Horváth János, 1998: Róma villa egykor és ma. - Rippl-Rónai Jó-
} zsef gyüjteményes kiállítása. 169 


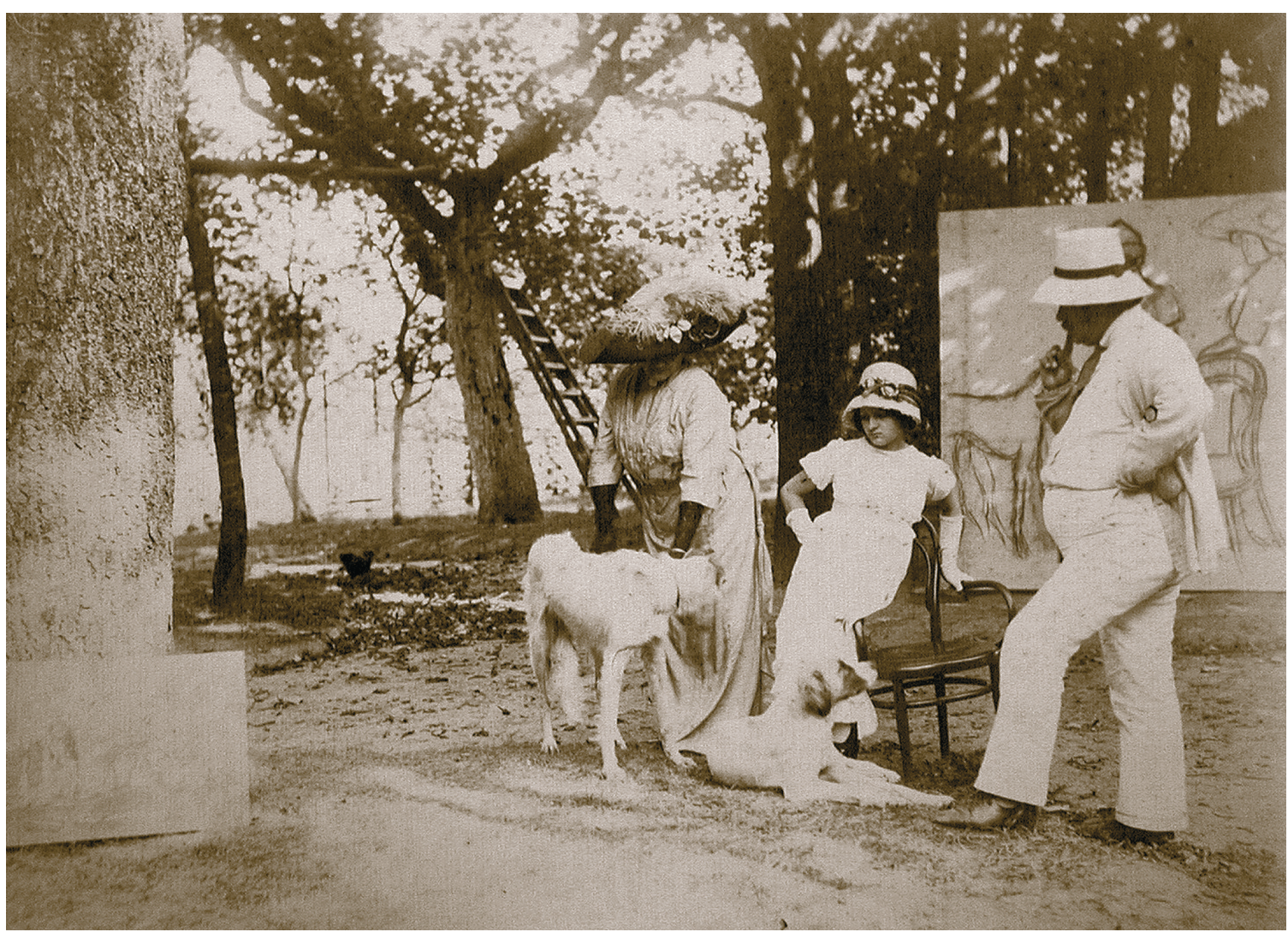

7. ábra. A Róma-hegyi kertben Rippl-Rónai festi Lazarine-t és Anellát, 1911. Fotó: Langsfeld fiai. Kaposvár, Rippl-Rónai Múzeum, archív fotó.

A Róma villa parkja a földi paradicsom, az újjászületés lehetőségét hordozó, árkádiai típusú hely. ${ }^{44}$ A megélt paradicsomi boldogság és természettel történő azonosulás Rippl-Rónai Meggyfavirágzás (1909) c. képén a tavasz himnuszává magasztosul (8. ábra). A virágba borult meggyfák tömör lombja szinte elborítja az égre nyíló kilátást. A sürün villódzó szirmok, bódító atmoszférával telítik az idealizált jelenet légterét. A vincellérház mellett zöld gyepen álló virágzó fák lila törzsü oszlopainak sürüjében középen egy nagyobb fa törzse és egy vele összeolvadó nőalak látszik. A hoszszú, lila ruhás, kalapos jelenség Lazarine, a művész kedvese, aki egyúttal megjelenítője a vágyódásnak, a természeti közelségében élésnek. Ez a kert a társas élet helyszíne is. Barátokkal, családtagokkal bővül a társaság. A franciaországi otthonát idéző, mély gyökerei vannak a „Meggyfavirágzásnak”, ugyanakkor a játékossá váló „kukoricás” elv kialakulásának fontos állomása ez a kép. ${ }^{45}$

A Róma villa magasságából szép panoráma nyílt a környező vidékre. A fel- és kiemelkedés érzése egyúttal a városon való felülkerekedés metaforája is. A Róma villában kikísérletezett kukoricás stílusban még markánsabban jelentkezett az a törekvése, amelyben

44 Keserü Katalin, 1998: Műfajok és mütípusok Rippl-Rónai művészetében. - Rippl-Rónai József gyűjteményes kiállítása. 133

45 Horváth János, 1998: Meggyfavirágzás, 1909. - Rippl-Rónai József gyűjteményes kiállítása. 326 a festő által diktált szilárd konstrukció adja a kép szerkezetének stabilitását. A „Tavaszi munkák” című képben az enyhe felülnézetben ábrázolt tájat a különálló ecsetgesztusok zsibongó, lüktető ritmusa hatja át. Az izzó sárga, zöld, rózsaszín, piros színek futamaiban a vízszintes sorok sík mezőt, a ferde sorok meredek lejtőket jelölnek, míg a hajlongó emberi figurák, a házikók és a fák fekete, piros, zöld, fehér ékkövekként kerültek a táj füzérébe. A munkálkodó emberalakok e síkokká redukált, szinte absztrakt konstrukció alárendelt, mozaikszerü részelemévé válnak. A kép teljes felületén végigvonuló, dekoratív ritmusban az emberi tevékenység és természettel való összeforrottság tökéletes összhangja nyilatkozik meg (9. ábra).

Ez az összhang a korszak egyik fő művében, a Modelljeim kaposvári kertemben - Festő a modellekkel (1912) c. müben az antik idill asszociációit keltve nyilatkozik meg. A művész egy Langsfeld nevű helybéli fotográfus fényképét használta fel hozzá, aki 1912ben riportképeket készíteni járt Rippl-Rónai otthonában. (9. kép) A Róma-villát körölvevő parkban készült fotográfián a nyárias viseletben, vászonkalapot viselő, csípőre tett kézzel pipázó művészt és feleségét, Lazarine-t illetve nevelt lányát, Anellát látjuk Olga kutyával, előttük a földön Heppy kutya hever. A müvész mögött festöállványon egy készülő, nagyméretű vászonkép is megjelenik felvázolt női aktfigurákkal. A cselekményszegény létezés, a szinte irreális hangu- 


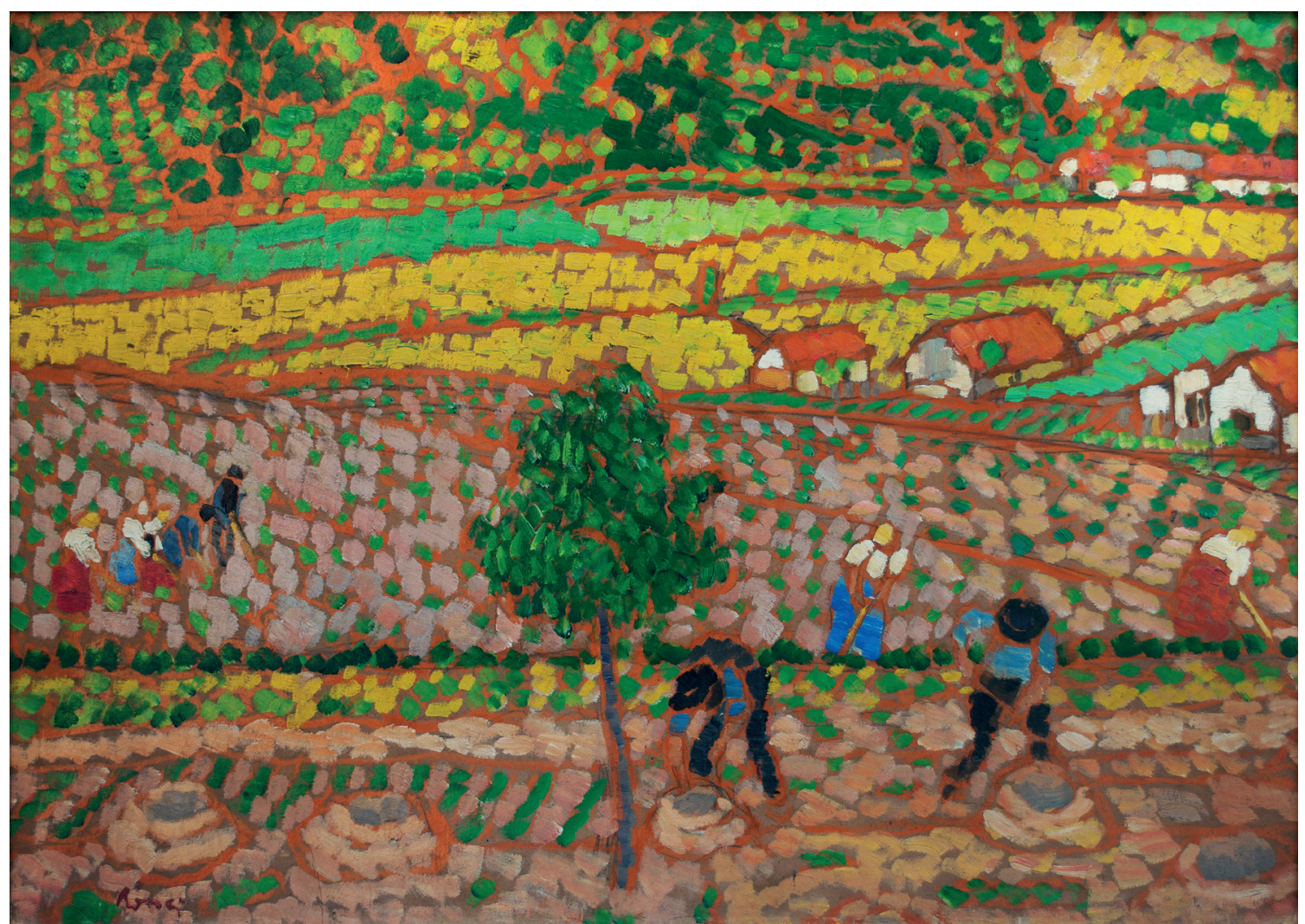

8 ábra. Rippl-Rónai József: Tavaszi munkák, 1912. olaj, karton 70x100cm, Rippl-Rónai Múzeum, Lsz: 63.4.

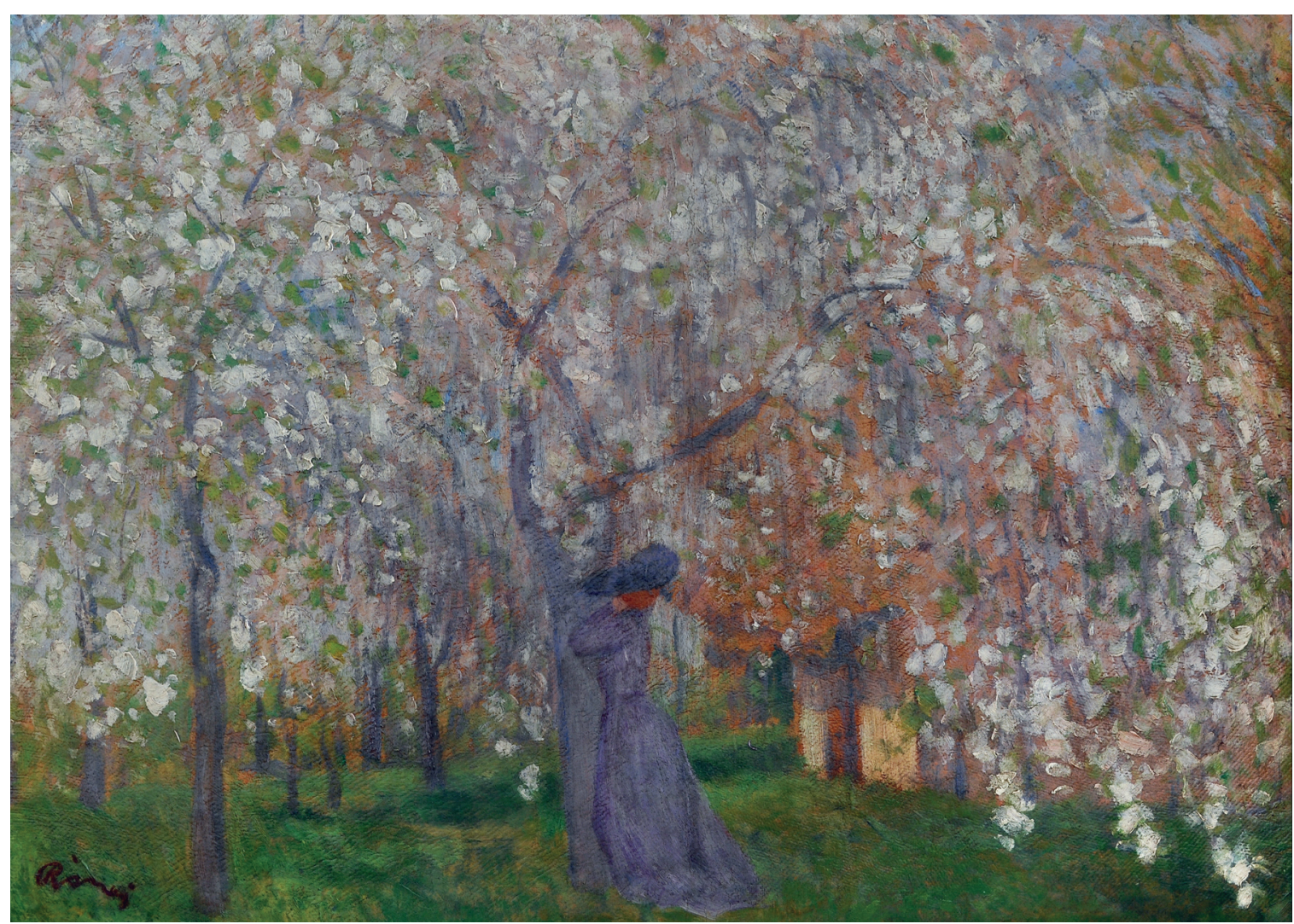

9 ábra. Rippl-Rónai József: Meggyfavirágzás. 1909. olaj, lemezpapír, $68 x 90$ cm, Rippl-Rónai Múzeum, Lsz.: 55.622. 


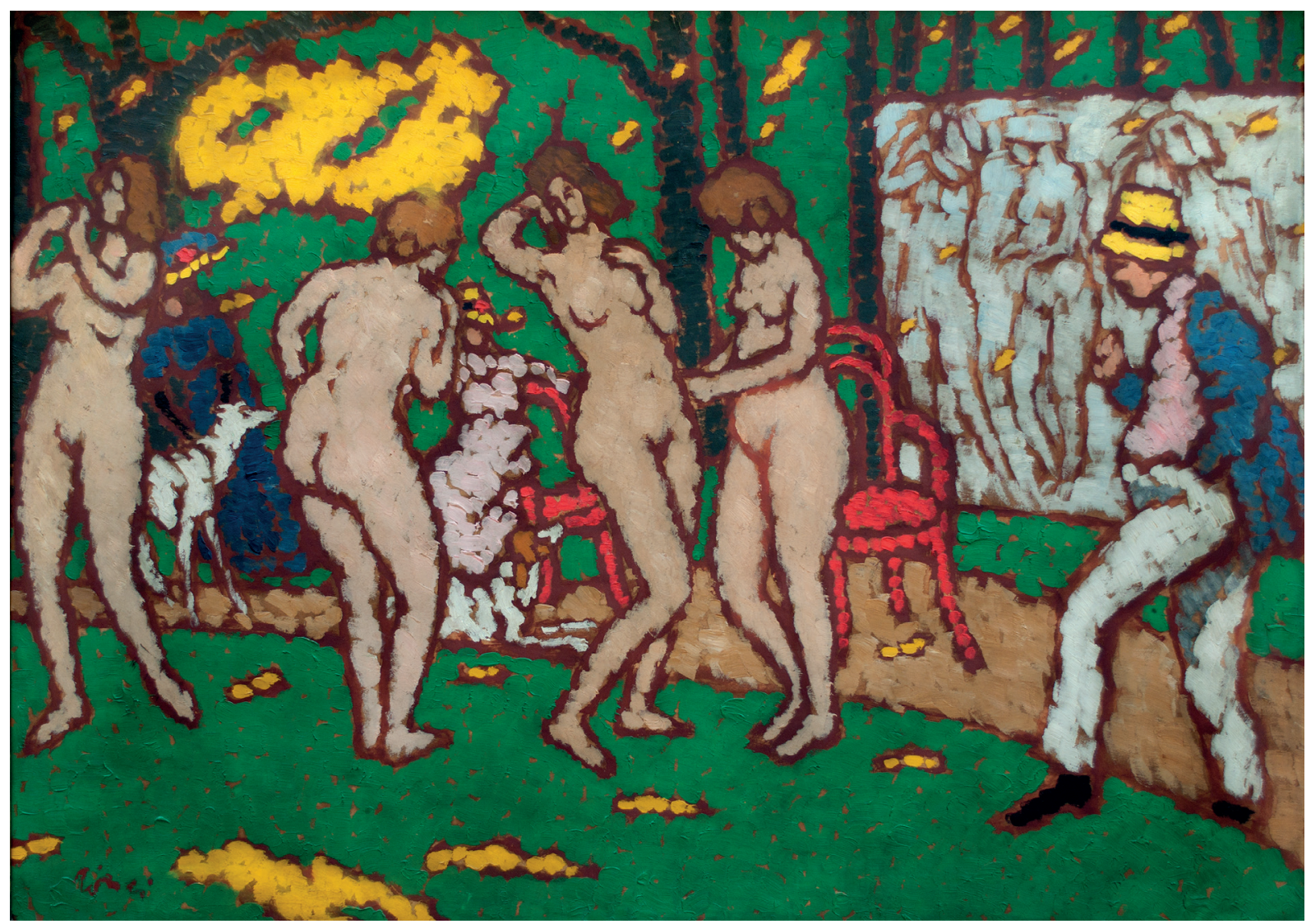

10 ábra. Rippl-Rónai József: Modelljeim kaposvári kertemben, 1911, olaj, karton, 70x100cm, Rippl-Rónai Múzeum, Itsz.: 81.8.1.

lat és az idillikus természet szinte kínálkozik a festészeten keresztül történő megragadásra. A fotóról hiányoznak a művész előtt mitológiai nimfákként pózoló aktmodellek, amelyek a festmény lényegi motívumai. Noha a festmény fotóból átemelt, konkrét elemekből épül fel, mégis metaforikus-szimbolikus tartalmakat közvetít. Horváth János a kép a képben motívumot vizsgálva a festményen felvázolt, készülő műalkotást egy másik világra nyíló ablakként értelmezi és anyagiságtól elvont, idealizált állapotként írja le a motívumot. ${ }^{46}$ Révész Emese Bacchus kertjeként értelmezi a képet, amely az ideális szépséget szemlélő művészről illetve mủvészet teremtő erejéről szól. ${ }^{47} A$ jelenet kedves humorral utal az ókori mitológiai istennők közül választó Parisra, akinek szerepébe ezúttal a festőművész kerül. A kibővített jelenet mindkét értelmezésben egy művészi vágyvilág megvalósítása: a festőművészetre utaló motívumokkal (aktok, festőállvány a készülő képpel és a maga a művész) egy figurára és tájra vonatkoztatott eszményigény megfogalmazása (10. ábra).

Rippl-Rónai, akit az 1910-es évektől élénken foglalkoztatott azt aktábrázolás, az árkádiai idill újra fogalmazását, aktualizálását hozta létre a mítosz és valóság e különös ötvözetében. A Róma villa a vidéki idill megvalósításának lehetőségét adta, amely megvalósított életeszményként műveinek alapvetően derűs, joviális világához hozzájárult. Az aktokkal kibővített kert az antik locus amoenus újra értelmezése, aktualizálása, és a természet, a női szépség és fiatalság a művészet ihlető forrása. A Róma villa kellemes természetidilljének lombokkal zárt kertjében (hortus conclusus) az isteni elem aktok alakjaiban (nimfák) ölt látható formát. ${ }^{48} \mathrm{Az}$ embert, természetet és istenséget magába foglaló együttes egy jól megragadható, univerzális rend része, amely az aranykor, az álom és a valóság között található ősállapotot őriz. Egy köztes világ, amelynek jellegzetessége a paradicsom és a valóság közti lebegő ellentmondás. Ily módon a mü kapcsolatot teremt Árkádia régi vágyvilágának mítoszával, ahol az ember a szabadidőben, a művészetben és bukolikus elmélkedésben találja meg önmagát. Rippl-Rónai e képében ily módon a város aktív élet (vita activa) törekvéseit a természet idilljében kifejezésre jutó vita contemplativával állítja szembe.

46 Horváth János, 2018: József Rippl-Rónai. Prvi majstor mađarskoga modernog slikarstva. 67.

47 Révész Emese, 2008: Rippl-Rónai József (1861-1927). Egy kisvárosi forradalmár élete és festészete.

48 Petra Maisak, 1981: Arkadien. Genese und Typologie einer idyllischen Wunschwelt. 241. 


\section{Irodalom}

BıBó I. 1989: Eltorzult magyar alkat, zsákutcás magyar történelem. Válogatott tanulmányok II.

BımBó M. 2013: A népi írók mozgalmáról. Eszmélet 99, (ösz) http:// www.eszmelet.hu/bimbo_mihaly-a-nepi-irok-mozgalmarol/

CSATÁRI B. 2004: A magyarországi vidékiségröl, annak kritériumairól és krízisjelenségeiröl. Területi Statisztika 7. (44): 6. 532-543

CsuRgó B. 2013: Vidéken lakni és vidéken élni. Argumentum Kiadó

DóKA K. 2019: „Népünnep” és nemzeti ünneplés (1896) Népszokás- és néptáncbemutatók az Ezredéves Országos Kiállitáson. Tánctudományi Közlemények 9

DR. KISS A. 1961: Az agrárnépességi viszonyok területi alakulása Magyarországon 1880-1960. Demográfia 1961.1

FeKETE Gy. 1929: Az ötven év elötti Kaposvár. Új-Somogy Nyomda, Kaposvár

FÓNAGY Z. 2015: A polgár otthona a boldog békeidőkben: ideál és valóság. 2015. február 8 . https://mindennapoktortenete.blog hu/2015/02/08/polgari_otthon

GAÁL Zs. 2009: A dzsentri születése. A Tolna megyei reformkori középbirtokos nemesség átalakulása a neoabszolutizmus és a dualizmus korában. Szekszárd

GÉGER M. 1992: Galimberti Sándor indulása (A müvész tanulóéveinek rekonstrukciója 1883-1903-ig Kaposvártól-Nagybányáig) Somogyi Múzeumok Közleményei 9.

GENTHON ISTVÁN kéziratos oeuvre-katalógusa a MTA MKI Adattárában. Ltsz: MTA MKCS-C-I-36/1155-4530

GYÁNI G. 2005: Budapest túl jón és rosszon. Beszélö 10 (3)

HANÁK P. 1988: Magyarország társadalma a századforduló idején. Magyarország története 1890-1918.

HAUSER A. 1980: Müvészet és irodalom társadalomtörténete, 2. Gondolat

HoRVÁTH G. K. 2015: Örökségünk és adósságaink. A rurális társadalomtörténet lehetőségei Magyarországon. Ethnographia, 126 (3). 417-433.
HORVÁTH J. 2008: A Rippl-Rónai tanítványok. Rippl-Rónai müvészetének hatása az 1910-es években Kaposváron, Somogy Megyei Múzeumok Igazgatósága, Kaposvár

HoRvátH J. 2018: József Rippl-Rónai. Prvi majstor mađarskoga modernog slikarstva. Zágráb

HoRVÁTH J. 2011: Rippl-Rónai 150. Kaposvár

HORVÁTH J. 1995: Rippl-Rónai emlékkönyv. Kaposvár

KovÁcH I. 2012: A vidék az ezredfordulón. A jelenkori magyar vidéki társadalom szerkezeti és hatalmi változásai. MTA Társadalomtudományi Kutatóközpont

KUNFFY L. 2006: Visszaemlékezéseim. Szerk: Horváth János. Kaposvár MODERN MÜVÉSZET, 1906. 4.

MAGYAR MűVÉSZEt 1890-1919. Akadémiai Kiadó, 1981.

MAGYARORSZÁG TÖRTÉNETE 1890-1918. Budapest, Akadémiai Kiadó, 1988.

MAISAK, P. 1981: Arkadien. Genese und Typologie einer idyllischen Wunschwelt, Frankfurt/ Bern

RÉVÉsz E. 2018: Rippl-Rónai József (1861-1927). Egy kisvárosi forradalmár élete és festészete. 2008.01.16. https://revart.eoldal.hu/ cikkek/muveszek-1900-1945/rippl-ronai-jozsef.html

RIPPL-RÓNAI 1903. november 23-án, Kaposváron kelt levele Kunffy Lajosnak. MNG Adattár, Itsz: 19761/77/1

RIPPL-RónAl JózSEF EMLÉKEZÉSEI / BeCK Ö. FülöP EMLÉKEZÉSEl. Budapest, 1957.

RIPPL-RÓNAI JózSEF GYÜJTEMÉNYES KIÁLLíTÁSA. A Magyar Nemzeti Galéria kiadványai, 1998.

SzABó Z. 1937: A tardi helyzet. Cserépfalvi Könyvkiadó

SziJúRTó I. é.n.: Kaposvár közmüvelödésének és müvészeti életének áttekintése a századfordulótói a felszabadulásig. Rippl-Rónai Múzeum adattár. kézirat

VIDÉKFEJLESzTÉs. Szerkesztö: Bálint János Nagy Géza. Debrecen, 2007. 
